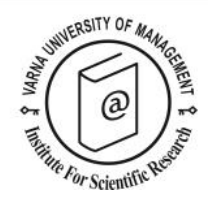

\title{
Tourism and water resources: interrelationships and consequences. The case of Kazakhstan
}

\author{
Makhabbat Ramazanova ${ }^{1 *}$
}

\footnotetext{
${ }^{1}$ University of the Balearic Islands, Spain. Carretera de Valldemossa, km 7.5, 07122, Palma, Balearic Islands, Spain Phone: +351 936732 776, E-mail: m.ramazanova9o@mail.ru

* Corresponding author
}

Supervisor: Prof. Bartolomé Deyá Tortella

Co-Supervisor: Associate Prof. Anuarbek Kakabayev

Institution awarding the Ph. D. Degree: University of the Balearic Islands, Spain

Date of defence: 03 June 2019

Citation: Ramazanova, M. (2020). Tourism and water resources: interrelationships and consequences. The case of Kazakhstan. Doctoral Dissertation Summary. European Journal of Tourism Research 26, 2611. 


\section{Goal and objectives of the dissertation \\ Goal}

Tourism and water are characterised by a significant and complex number of different, and sometimes bidirectional, interrelationships (Gössling et al., 2012; Tortella \& Tirado, 2011). This research area is relatively new and there is a significant deficit in the body of literature concerning this area (Gössling et al., 2015; UNWTO, 2013). In this context, the aim of this research project is to examine the interrelationships and consequences of tourism and water resources from various perspectives: the impact of tourism on water resources, water consumption in the tourism sector, and the attractiveness of water resource attributes for tourism activity.

\section{Objectives}

Based on the main aim, the present thesis is designed to accomplish three objectives:

- To examine the possible impacts of tourism activity on water resources (quality of water in a lake environment), with the intention of understanding the consequences arising from the growth of tourism activity on water-based and lake destinations;

- To understand the main drivers that can explain the behaviour of water consumption within the lodging sector, as the highest water consumer within the tourism industry;

- To analyse the importance of water as a part of a lake destination image, as well as the behavioural intentions of visitors in a lake destination (i.e. relationship between lake destination image, motivations, satisfaction and loyalty).

\section{Methodology}

The study area is the Shchuchinsk - Burabay resort area, located in the Akmola region of the Northern Kazakhstan, which is one of most water-deprived countries in Central Asia (UNDP, 2004). This region is one of the most important tourist destinations of the country and accumulates a relevant number of lakes. The data has been obtained from the Committee on Statistics, Department of Tourism and Department of Statistics in Akmola region and Water Resources Committee of the Republic of Kazakhstan. Two survey questionnaire tools were developed (based on previous literature on specific topics). The first survey questionnaire was conducted among accommodation business managers (representative sampling approach) and the second survey was conducted with the visitors to a lake destination (convenience sampling approach).

To examine the changes in lakes' surface area, along with evolution of the number of tourism accommodation units located around each lake, the abilities of GIS technologies were applied. To identify the main drivers of water consumption within tourism lodging sector, the multiple regression methodology was employed to a representative sample of the accommodation businesses in the region from April till July 2016. The sampling technique has been the stratified random procedure, applied to 150 lodging types of the region. As a result, 51 valid and complete surveys (face-to-face) with lodging managers were collected and analysed.

To examine the relationship between the image of a lake destination and its antecedents (such as motivation) and consequences (overall satisfaction and lake destination loyalty) partial least squares structural equation modelling (PLS-SEM) was used. To apply the model, an empirical study was conducted with 450 visitors (face-to face and online) in March - April 2018. As a result, 366 completed and valid surveys were collected, with an $81 \%$ response rate. A convenience sampling approach was adopted to select the visitors to include in the sample. 


\section{Results}

The results obtained in our research indicate that the lakes of the region are facing environmental issues in terms of surface area decline and water quality deterioration (Yapiyev et al., 2017). One of the possible determinants of this phenomenon could be the growth observed in the tourism lodging facilities in the study area. In this context, our findings reveal that the lodging sector is responsible for a considerable part of water consumption within the tourism industry. A water consumption indicator (water consumption per guest per night) has been defined. These findings are comparable with those observed in hotels in different regions of the world (Gössling et al., 2015). In respect of to the factors that determine the levels of water consumption, the results conclude that the size of the facilities and the pools, the number of meals served constitute significant variables to explain water consumption (Tortella \& Tirado, 2011). The study concludes that sanatoriums are those types of accommodation with higher levels of water consumption (probably due to the nature of health and wellbeing services included in these facilities), while guesthouses are those with lower levels. Our study also reveals that the introduction of water-saving measures, despite their reduced implementation, constitutes an effective tool in reducing the levels of water consumption.

About the lake destination image analysis, all hypotheses are supported, except the hypothesis, that the motivation "socialising and being active" has a positive impact on the inexistence of pressure. The hypothesis, which predicts that water quality positively affects lake destination satisfaction, has also not been supported. It is interesting to note, that water quality was the only dimension that did not have a significant impact on satisfaction within the overall lake destination experience, despite its high influence on satisfaction with the lake. This finding corroborates, in some way, with previous studies where polluted lakes did not prevent people from visiting lake destinations (Ryan et al., 2010). Nevertheless, it is certainly of value to improve water quality, due to its high influence on satisfaction with the lake and significant impact of the motivations of socialising and being active as well as relaxing and healthy improvement on water quality dimension of the lake destination image, showing that this dimension is of major importance, creating valuable opportunities for visitors with these motivations.

\section{Theoretical conclusions}

From a theoretical perspective, the thesis provides insights into the importance of water resources for tourism activities, water consumption in the tourist industry, the impact of the tourist sector on water resources and the attractiveness of lake water environment for tourism activity. This contributes to expanding the geographical scope of research related to tourism-water nexus.

It helps to understand water quantity and quality challenges that the lakes may face due to tourism activities (Hall \& Härkönen, 2006). Another issue is that lakes' environmental issues are responses to other natural (climate change) and anthropogenic factors (local population, industry, agriculture, etc.). The study also sheds light on the application of GIS technology in tourism research, indicating possibilities of using GIS to obtain data for long periods of time. From the perspective of water consumption behaviour of the lodging sector, the research identifies a set of key factors to explain water consumption. Furthermore, this work contributes to expanding the research on destination image applied to lake tourism context. It allows the identification of comprehensive set of items that may be adopted to assess the lake destination image (Rodrigues et al., 2015).

\section{Practical application of the dissertation}

The findings of this thesis provide important practical implications for policymakers, planners and managers of lake destination, as well as accommodation business managers. According to our findings, water quality and quantity of the main lakes in the region are facing negative environmental issues. 
Thus, it is crucial that future tourism and water management policies take into account the effects of tourism activity on lake water resources, and it is also crucial for the success of the tourism destination, and for the sustainability of the region. Moreover, and according to the Water Code of the Republic of Kazakhstan, water bodies and resources which have natural healing properties, as well as those which are amenable to therapeutic and preventive purposes, belong to the health category and are used for the purposes of recovery in accordance with the laws of the Republic of Kazakhstan (Water Resources Committee, 2015). Hence, as most tourism water consumption is related to the accommodation sector, significant attention should be paid to this sector. The accommodation sector could contribute to improving water lake quality by, for example, building sewage treatment systems and appropriate mitigation systems.

About lake destination image, managers of lake destinations should explore the potential of lakes for both relaxation and health improvement, as well as for socialising and engaging in activities. It is crucial to improve water quality of the lakes regarding all components, due to its strong impact on satisfaction with lakes and its relevance to those looking for opportunities to socialise and actively engage in waterbased activities.

\section{Content of the dissertation}

Abstract of Chapter 1

Chapter 1 provides the reader with an overview of current research in the field (state of art). The general structure of the thesis is also presented in the introduction chapter.

\section{Abstract of Chapter 2}

Chapter 2 provides information on the state of water resources in Kazakhstan, outlining the Shchuchinsk-Burabay resort area, located in Akmola region, as a case study area.

\section{Abstract of Chapter 3}

Chapter 3 exposes the particularities of the tourism industry, along with its evolution in Kazakhstan and Akmola region, with particular attention paid on the accommodation sector.

\section{Abstract of Chapter 4}

The fourth chapter of the thesis aims to examine the changes in the lake surface area; to analyse the evolution of the tourism industry in the region; to discuss direct and indirect effects of tourism activities on lakes, in terms of quantity and quality along with other factors determining environmental state of the lakes; to examine the variation of the lake surface area and tourism growth nexus based on GIS technology outputs.

\section{Abstract of Chapter 5}

Based on the knowledge of previous studies developed worldwide, chapter 5 of the thesis aims to analyse water consumption in the lodging sector. The objectives of the present chapter are to identify water consumption indicators in various accommodation types and determine the main drivers that affect water consumption. A model has been developed which includes a set of potential variables to explain water consumption at the lodging facilities of the Shchuchinsk - Burabay resort area.

\section{Abstract of Chapter 6}

The chapter 6 of the thesis focuses to overcome the gap on lake destination image. The specific objectives of this chapter are to determine the concepts of lake image and lake destination image; assess 
the influence of individuals visit motivation on lake destination image, and finally to analyse the influence of lake destination image on overall satisfaction with the lakes and lake destination, and its effects on loyalty. A structural equation model is used to examine the relationship between lake destination image and its antecedents and consequences.

\section{Abstract of Chapter 7}

Chapter 7 provides a synthesis of the key findings of the thesis, and their potential implications and limitations. The chapter discusses suggestions for future research and the contribution of the thesis.

\section{References:}

Gössling, S., Peeters, P., Hall, C. M., Ceron, J. P., Dubois, G., \& Scott, D. (2012). Tourism and water use: Supply, demand, and security. An international review. Tourism management, 33(1), 1-15.

Gössling, S., Hall, C. M., \& Scott, D. (2015). Tourism and Water (Vol. 2). Bristol, Buffalo, Toronto: Channel View Publications.

Hall, C.M., \& Härkönen, T. (2006). Lake tourism: An Introduction to Lacustrine Tourism Systems. In Hall, C. M., \& Härkönen, T. (Eds.), Lake tourism: An integrated approach to lacustrine tourism systems (pp. 3-26), Clevedon, Buffalo, Toronto: Channel View Publications.

Rodrigues, A. I., Correia, A., Kozak, M., \& Tuohino, A. (2015). Lake-destination image attributes: content analysis of text and pictures. Advances in Culture, Tourism and Hospitality Research, 10, 293-314.

Ryan, C., Huimin, G., \& Chon, K. (2010). Tourism to polluted lakes: issues for tourists and the industry. An empirical analysis of four Chinese lakes. Journal of Sustainable Tourism, 18(5), 595-614.

Tortella, B. D., \& Tirado, D. (2011). Hotel water consumption at a seasonal mass tourist destination. The case of the island of Mallorca. Journal of environmental management, 92(10), 2568-2579.

Yapiyev, V., Sagintayev, Z., Verhoef, A., Kassymbekova, A., Baigaliyeva, M., Zhumabayev, D., \& Jumassultanova, S. (2017). The changing water cycle: Burabay National Nature Park, Northern Kazakhstan. Wiley Interdisciplinary Reviews: Water, 4(5), 1-14.

U. N. D. P. (2004). Water resources of Kazakhstan in the new millennium. Almaty, Republic of Kazakhstan: UNDP Publication in Kazakhstan.

UNWTO. (2013). World Tourism Day 27 September 2013. Tourism and Water: Protecting our Common Future. Madrid, Spain: World Tourism Organization.

Water Resource Committee of the Ministry of the Agriculture of the Republic of Kazakhstan. (2015). Water Code of the Republic of Kazakhstan. Retrieved November 52015 from http://cwr.kz/index.php?option=com_blog_calendar\&year=2011\&month=12\&mo $\operatorname{did}=47 \&$ Itemid $=0$.

Received: 21/10/2019

Accepted: 30/05/2020

Coordinating editor: Faizan Ali 